\title{
CONTEMPORARY RESEARCH ON THE WHITE CLOTH AS A RITUAL ITEM IN THE BULGARIAN WEDDING: ANTHROPOLOGICAL APPROACH
}

\author{
Rozaliya Guigova
}

\begin{abstract}
The aim of this article is to investigate the white cloth in the contemporary urban Bulgarian wedding in anthropological perspective. The white cloth as a ritual item in the contemporary urban wedding ceremony is a simple white rectangular fabric, usually made of cotton, which looks like a path on which the newlyweds have to walk during the wedding celebration. Immediately after entering the restaurant in which the wedding party is held, they step on the cloth. At this point a number of symbolic actions are performed, involving ritual items and characters.

Based on profound fieldwork materials gathered by the author, the paper discusses the fertility function of the cloth and its protective qualities regarding the methods of the functioning of the cloth as a ritual object in the sphere of symbolic thinking today. In this paper, this ritual object is interpreted also in a social context, in the sphere of ritual practises in contemporary and traditional weddings, as an item by means of which people consciously or unconsciously fix a boundary between the public and private spheres of their existence; on the other hand, it is analysed as an object that metaphorically expresses kinship links. The author argues that, as a result of the changed socio-cultural characteristics of the Bulgarian society today, the tradition of close kin relations, which is expressed through objects, gradually loses significance.
\end{abstract}

Keywords: kinship relations, ritual objects, traditional culture, urban customs, wedding, wedding procession, white cloth

\section{INTRODUCTION}

The traditional Bulgarian wedding has often been the subject of research interest (Arnaudov 1934; Vakarelsky 1974). Regarding the traditional wedding, I can mention several substantial monographic studies: a great volume dedicated to the ethnology of the Sofia region (Sofia 1989), since my urban field research has been done in Sofia, a remarkable monographic research of the Slavic traditional wedding (Gura 2012), especially the volume that analyses the symbolism of objects, and a special monographic research dedicated to the 
Bulgarian wedding (Uzeniova 2010). Nevertheless, the investigation of the ritual practices and objects in the contemporary urban Bulgarian wedding has, to some extent, remained out of focus. In spite of all this, the research of some authors has been devoted to the rites of the life cycle in traditional and contemporary Bulgarian culture (Ivanova 2000; 2002). Therefore, I think that it seems appropriate to emphasise the fact that interesting perspectives of traditional rites could be seen in the contemporary urban wedding as well as in the way that the ritual objects are functioning in it. A good example of this is the white cloth (bialoto platno).

The white cloth is a ritual object that nowadays can be seen nearly at every urban Bulgarian wedding. It is a simple white uncut cotton cloth that always has a rectangular shape. This fabricated item is normally store-bought and is generally spread out in the restaurant in which the wedding celebration takes place. Also called "sponsor's cloth" (bialo platno ot kumata), it is sometimes covered with scattered flowers - geraniums, carnations or rose petals. It looks like a white path, on which the newlyweds have to step immediately after entering the restaurant. During the wedding party many ritual actions are performed, with the cloth placed on the floor of the restaurant, as, for instance, breaking of glasses full of wine, breaking of the wedding bread, etc. A detailed description of the corresponding ritual practices is given below.

The cloth in Bulgarian culture has a major significance and it features symbolism. In traditional culture, after baptism the Godfather swaddled the child in a piece of new white cloth (Ivanova \& Zhivkov 2004). The cloth (platno, peshkir, karpa) is a common gift in traditional and contemporary rituals of the life-circle. The traditional wedding flag (bairak, stiag, feruglitsa, priapor), which can be seen also in some contemporary urban weddings, is made of a red or white cloth. A child walks on a white cloth, placed in front him or her during ritual actions that are performed in order to celebrate the toddler (proshchapulnik). A redcoloured non-transparent cloth covers the bride's head and face in traditional culture. In traditional as well as in some contemporary weddings the bride enters the groom's home, walking on a white cloth (Ivanova \& Zhivkov 2004). In traditional society the departed is covered with a shroud - a long piece of white cloth. The cloth is considered as a symbolically significant ritual item by many Slavic societies (Tolstoi 2009). Many similar examples could be provided, but here I would confine myself to the abovementioned, as it is not the main subject of my research to investigate the complex symbolic system embodied in this ritual object. Nevertheless, those examples provide a background to my investigation of the white cloth in the contemporary wedding.

In this context, I proceed from the perspective presented by Albert Baiburin, who has developed the idea that objects have a dual nature because every object 
can be used both as an object and as a sign. Each artificially produced object has utilitarian and symbolic characteristics and can potentially be "implemented" as an object or a sign. In this way the existence of objects can be presented as a specific semiotic fluctuation (Baiburin 1983: 9). So objects of the present day can be discussed in various aspects: in their relationship to the objects functioning in what has been referred to as traditional culture, as bearers of the family memory, and as exponents of social relations. On the other hand, we can trace their subordination to cultural globalisation and mass media. They contain many cultural and social meanings, which are sometimes beyond any objective signification because they depend on the cultural and social context. From this point of view, in this article the white cloth is discussed as a ritual object operating in the present-day wedding, and is compared to the cloth in the traditional wedding. ${ }^{1}$

In the present day, the white cloth is an object of an utilitarian purpose, but when operating in the sphere of ritual practice, it acquires signification features: the cloth is a metaphor of the path that the couple starts together; the cloth, as well as the arch that is placed in front of it, symbolically signifies the entrance to the new life that the newlyweds step into together. In this paper, the cloth, which in the present-day Bulgarian wedding is spread out in a restaurant to welcome the newlyweds, is compared to its usage in the traditional ritual, at which the bride passes on a white string or belt when entering the bridegroom's house. Today in some wedding ceremonies in Bulgaria the white cloth is spread out in the house of the newlyweds, at other weddings it is spread out in front of the house of the groom's mother when she receives the newlyweds at the end of the wedding day, or is even placed in front of the registry office. Both at the contemporary and traditional wedding, this ritual object could be interpreted in a social context as a metaphorical expression of the kinship link in the family. On the other hand, it is also regarded as a symbolic element in the rite of passage.

I think that wedding and the rites of the life cycle are preserved as effective symbolic actions in contemporary Bulgarian culture. The objects that function here are connected with the personal life and fate of people; that is why belief in their magic qualities and their semantic meaning remains "alive". Furthermore, I think that they also continue expressing a social meaning. Different examples could be given of this. According to my fieldwork results, the bride, throwing a flower bouquet behind her back, often believes that the one that catches the bouquet will be the next to get married. The object will magically transmit the status of its owner over to the person that receives it. Also, in a traditional Bulgarian wedding the bride leaves several patterns in her costume embroidery half-finished, because a garment without imperfection would attract hidden 
evil forces. In the same manner and maybe because of the same belief, the present-day Bulgarian bride unstitches the lining of her wedding dress in several places. Both of them are obliged to accomplish that action secretly, with no one's knowledge. Therefore, I think that some of the objects today may change their material shape, could be susceptible to fashion influences or technology of production, but they continue existing in rites, following the logic of cultural continuity between tradition and contemporary culture. Therefore, the white cloth that is placed today in a restaurant during a wedding ceremony could also be seen as the carrier of cultural continuity. In this context, I hereby also investigate the ritual function of the white cloth in urban culture, as far as culture is understood in a more general sense of the process, through which human groups construct themselves and socialise (Miller 1994: 399). Culture is always a process rather than a set of objects, such as the arts, and it should be seen as an evaluation of the relationship through which objects are constituted as a social factor (Miller 1987: 11).

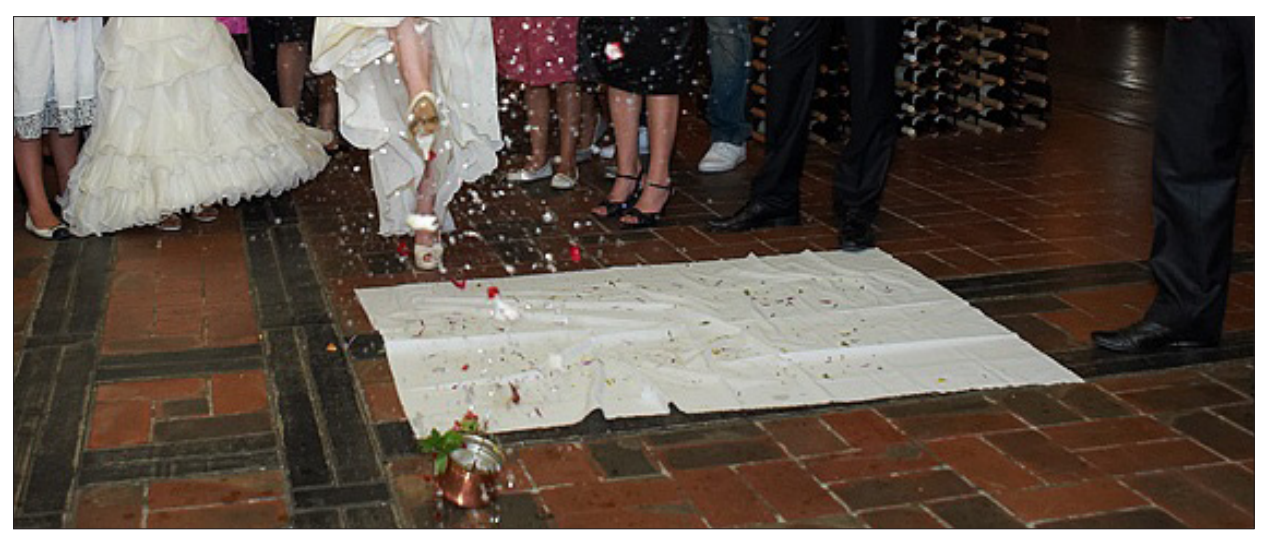

Figure 1. The bride kicks the jug while stepping on the white cloth in a restaurant in Sofia. Photograph by Ivan Stoyanov 2012.

I collected the material for the article (interviews with informants, documentary photographs and material gathered during personal attendance of weddings) in the course of my fieldwork in urban social environment, undertaken in three Bulgarian towns - Stara Zagora, Svilengard and Sofia ${ }^{2}$ - within the period 1999-2004. An important part of my fieldwork investigation are Internet forums, in which girls from all over the country exchange information about their wed- 
ding days or the future arrangement of their own or somebody else's weddings. All of them come from medium-sized cities as, for example, Plovdiv or Varna ${ }^{3}$, and the information has been published by them on the Internet between the years 2006 and 2012. My informants are well educated women between the ages of 23 and 65 . All of them live in the capital or in some medium-sized town and all of them are ethnic Bulgarians.

The research methodology that I have adopted in my work includes ethnographic fieldwork and participant observation (interviews recorded during the fieldwork); research into the narratives that are published in Internet forums; analyses of wedding photographs that were kindly delivered to me by my informants; description and analyses of my personal participation in several weddings.

\section{THE CLOTH}

On a worldwide scale, the cloth expresses complex moral, ethic and ethnic issues, which are related to dominance and autonomy, opulence and poverty, political legitimacy and succession, gender and sexuality (Weiner \& Schneider 1989). It constitutes important forms of social interaction, which are dictated by family and community ties (Askari \& Arthur 1999). The uncut cloth is considered sacred and holy in many cultures as, for instance, in south-Asian societies (ibid.: 21). It is used as a baby's first swaddling band, circumcision wrap, coming-of-age veil for girls, a ritual wedding gift and the final enveloping shroud in a burial (ibid.: 21). Furthermore, it has strong possibilities for communication expressed through its shape, colour, patterns and structural elements, and displays endless variability of significations. An object that discloses many possibilities for attaching meaning can also conceal or homogenise differences through uniforms or disguise identities through costumes and masks. Cloth metaphors eco from many parts of the world, not only from the past but also from today (Weiner \& Schneider 1989: 2). The production of the cloth itself (in mythology and ritual practice) draws analogies between weaving and dyeing and the life circle of birth, maturation, death and decay. Thus, the cloth is established as a connection that binds humans to each other and to ancestors. On the other hand, the cloth operates as an object of bestowal and exchange, acquiring a social and political meaning. Participants in life-cycle celebrations frequently make the cloth a continuous threat, a connecting tie between two kinship groups, or three or more generations. Cloth as dress gains meaning as part of the culturally constituted body, which also means that it draws boundaries between the cultural and natural worlds in social and ritual contexts (Perani \& Wolff 1999: 1). 
One more dimension of it is the capitalist production, which re-decoded the symbolic potential of the cloth, eliminating the opportunity for weavers and dyers to infuse their product with spiritual value, and encouraged the growth of cloth fashion as a consumption system of ever-changing variation (Weiner \& Schneider 1989: 3). Finally, the cloth is also manipulated as clothing, used as table cloths or adornment, revealing or conceiving identities and values (ibid.).

\section{THE WHITE CLOTH IN THE URBAN BULGARIAN WEDDING}

Today, the ritual actions performed with the cloth at the Bulgarian wedding are known in different variants and I will depict them briefly below, based on my fieldwork investigation in Bulgaria. I will concentrate on one of its domains of expressions - the white cloth, spread out in the restaurant during the wedding ceremony - although the cloth in the Bulgarian wedding exists also as a bridal veil, tablecloth, dowry and bride-price, and a wedding gift.

During the contemporary urban Bulgarian wedding a white cloth is spread out in the restaurant. As already mentioned above, it looks like a white path, on which the newlyweds have to walk. It is a simple white uncut piece of fabric that always has a rectangular shape. It is also called the "sponsor's cloth", and it is a fabricated item that is normally bought, but on rare occasions the maid of honour (kuma) sews it. As a rule, the guests are the first to enter the restaurant, and when all of them have taken their seats, the couple follows. At some weddings the bridesmaid (shaferka) passes first and covers the cloth with wild geraniums, carnations and roses ${ }^{4}$; then follow the newlyweds. In recent years, companies and wedding agencies have emerged, which prepare the cloth, decorate it with flowers and construct something like a stand adorned with artificial flowers, placed as a hedge along the path. Generally the Godfathers (kr"stitsi) or sponsors (kumove) $)^{5}$ walk on the cloth behind the couple, roll it up and give it to the bride. ${ }^{6}$ The couple stops at the end of the path. The restaurant singer or the bride's father gives them two glasses of wine. The couple takes a sip of wine and throws the glasses over their heads, so that they break into pieces. The organiser, who sometimes is a person from the restaurant staff or somebody working for a wedding agency, says: "As many pieces are there as many boys will be born!" or "As many pieces as many boys and girls will be born!" The belief tells that the newlyweds must not turn and look back, and that the broken glass "brings health". ${ }^{7}$ The organiser fetches one small flat loaf of sweet "ritual bread" (obreden khliab) ${ }^{8}$ and the mother-in-law takes two morsels covered with honey, and gives them to the couple, putting them in their mouths. According to many informants, this ritual action is performed "in order 
to bring them a sweet life". The chronologically following ritual action requires that the couple hold the sweet "ritual bread", decorated with ornamentation and flowers and made of flour, in their hands, and raise it above their heads, trying to break it into two big pieces. My informants told me that according to the belief, the one "who holds the bigger piece will bear the responsibility for the family life". Sometimes this action is performed while the couple is standing on the cloth. After that, the bridegroom takes the bride in his lap and carries her to her seat at the wedding table. At some weddings, a small traditional copper jug (menche $)^{9}$ with water and roses is placed on the white cloth in front of the couple. The organiser says: "Let's see who is the first to kick the bowl!" The bride kicks the bowl and the water spills. ${ }^{10}$

According to the fieldwork materials that I collected, in some contemporary urban weddings the ritual role of the cloth as an object with a symbolic meaning is more broadly displayed. During a wedding that took place in Stara Zagora city in 2002, a cloth was placed on the restaurant floor. It had been bought by the groom's mother. The organiser of the wedding and the DJ decorated it with wild geranium, white and pink gladiolus and red rose petals. The couple walked on it and threw their glasses over their heads and after that three children, one after another, gifted the bride with a white, red and pink flower. At the same time, the organiser cited a verse that she herself had composed, in which the symbolism of these colours was interpreted, inspired by the popular urban culture. It can also be found in many Internet wedding forums: white - the symbol of purity, red - the symbol of love, and pink - the symbol of mutual understanding.

In some Bulgarian weddings, the spread cloth on the floor is the place where another ritual action is performed: that is the symbolic delivery of fire from the old family to the new. In this case, both fathers-in-law hold in their hands burning candles that, according to the informants, are "symbols of fire". They fuse the flames of the two candles and the couple lights a candle from the flames of their candles, i.e., according to the informants in that symbolic way "from two old families a new one is created". After that, the organiser folds the cloth, with all the flowers and pieces of broken glasses in it, hands it to the groom's mother and tells her that she has to keep it for three days and after that clean it. According to my informants, the tradition also says that it has to be kept one week, instead of three days, and that from this cloth the mother-in-law has to sew a bedsheet for the first child of the new family. ${ }^{11}$

There are many internet forums in Bulgaria where young girls exchange information about their weddings, narrating about different objects involved in the wedding rite. I have included here only their opinions in relation to the cloth, although in those forums the information about it, repeatedly called the "sponsor's cloth", is mixed with narratives about different wedding rites. ${ }^{12}$ 
Kazhete mili momicheta, bialoto platno triabva li da se porabva? Pitam, zashchoto na kumata mi sa i kazali, che ne bilo dobre da ima podgavi $i$ da e zashito po rabovete... Ne znam, dali go obiasnikh iasno, no tai kato tia sama si go pravi $i$ se chudi?

Tell me, dear girls, if the white cloth has to be trimmed. My maid of honour was told that it is not a good sign if the cloth is bordered and its edges are folded and sewn. I do not know if I explained it clearly but I ask you because she does not know what to do. She sews it single-handedly.

Ako stava vapros za tova bialo platno,koeto e $v$ restoranta az znam, che netriabva nikoi drug osven mladozhentsite da minava po nego, no za rabove nikoga ne e stavalo duma. A pak $i$ te ne go li predostaviat $v$ restoranta? Samo tova moga da ti kazha,za da ne te izlazha neshcho! If you are talking about the piece of white cloth that is spread out in the restaurant, what I know is that nobody else has to step on it except for the newlyweds, but I do not know if you have to put a hem on it... Is it [the cloth] not given to you by the restaurant staff? That's all I can tell you.

Nasheto shche e ot restoranta, kakto i mencheto, koeto se rita tam. A tova $s$ rabovete veroiatno e porednoto sueverie.

We will get the white cloth and the jug (menche) from the restaurant staff. The belief regarding the trim is probably one more superstition.

...za bialoto platno i na men niakoi mi kaza, che ne triabva da e porabeno $i$ da e pamuchno, no vse si mislia, che i tova e vid svoeverie.

Somebody told me that the white cloth must be made of cotton and that it does not have to be hemmed, but sometimes I think that it is some kind of superstition.

Momicheta chudia se kak da aranzhiram platnoto. Daite idei. Prilozhete snimki ot vashite suatbi.

Girls, I do not know how to decorate the cloth. Give me some ideas! Attach some photos of your weddings!

Obikoveno na sutabite prosto razpraskvat listentsa po platnoto, na men mnogo mi kharesva varianta na snimkata $i$ smiatam na moiata svatba da e taka.

Generally, only some petals are scattered over the cloth, but I really liked the photo that you attached and I will do it the same way at my wedding. 
Az sam reshila da zanesa da mi izbrodirat bukvite ot imenata ni i datata na svatbata varhu platnoto i tai kato sam se zakhvanala da razkrasiavam svatbata s blestiashchi kamacheta (tip "Svarovski") mislia da zalepia takiva i varhu platnoto, kolkoto leko da blesti. Inache sigurno pak shche porasim zdravets $i$ rozovi listentsa pokrai nego.

I've decided to ask somebody to stitch the first letters of our names and the wedding date on the cloth. I decided to embellish my wedding with shiny crystals (Swarovski style) and I think I will stick some Swarovski crystals on the cloth in order to make it shine. I'll probably sprinkle geranium and rose petals all over it.

It is obvious that the girls, although saying that it is nothing more than superstition, are really concerned with whether the cloth should be fringed or not, where it has to be placed and what to do with it after the wedding, and they even exchange photos of the white cloth, which means that it is an object of high significance in their wedding ceremonies. Some of the interlocutors keep it after the wedding, wash it, fold it, and put it in a wardrobe at home. In the same internet forum some more interesting opinions are mentioned:13

Bialoto platno s posipani zhivi tsvetia izraziava svetlina $i$ bezoblachen zhivot, kam koito se stremiat mladozhentsite.

The white cloth and the sprinkled flower petals express the idea of a bright and serene life, to which the newlyweds aspire.

...v nashiia krai vmesto po shampanskoto polat na detsata se opredelia po drug nachin. Oshche kogato bulkata $i$ mladozhenetsat sa na bialata pateka, pred tiakh se slaga ukraseno menche s voda i niakolko kitki karamfil, koito sa beli i cherveni... bulkata triabva da ritne mencheto, taka che karamfilchetata da izpadnat, gleda se tsveta na nai-dalechnoto karamfilche $i$ ako e cherveno - parvoto dete se ochakva da e momiche (primerno), ako e bialo-momche (vapros na ugovorka).

In our region, instead of champagne [the narrator means the pieces of broken champagne glasses], the gender of the future children of the newlyweds is determined in another manner. When the bride and the groom step on the white cloth, a jug full of water, decorated with carnations, is placed in front of them. The carnations are red and white. The bride kicks the jug and the carnations fall on the floor. The colour of the most distant carnation is observed: if it is red, the first child of the newlyweds is expected to be a boy; if it is white, the firstborn child will be a girl. 
Momicheta, a vsichki neshcha po posreshchaneto $v$ restoranta (bialoto platno $i$ tsvetiata po nego, mencheto, shampanskoto $i$ chashite, koito se chupiat) vie li si gi osigurikhte ili sa ot restoranta? Vizhdala sam po snimki, che bialoto platno sled tova se naviva na rulo ot kumuvete $i$ se dava na maldozhentsite... No te kakvo praviat s nego posle? Pazi li se ili pak neshcho drugo?

Girls, I want to ask you whether all the things (the white cloth, flowers, jug, champagne and glasses) were delivered by the restaurant staff or you bought them yourselves. I have seen in some photos that after the wedding the white cloth is rolled up by the sponsors and is given to the newlyweds ... But what do they do with it? Do they keep it or something else is done with it?

Vsichko tova nie si go osigurikhme, niama nishcho ot restoranta. Platnoto se naviva ot kumuvete $i$ se schita za parviia podarak za mladozhentsite. Az go izprakh i go pazia, bez staklata razbira se. Taka che imame dve platna, tova plius platnoto na koeto biakh stapila, kogato me vzimakha, za da me obuiat.

We bought all those things, nothing was provided by the restaurant staff. The cloth is rolled up by the sponsors and is regarded as the first gift to the newlyweds. I washed it and I still keep it, without the shards, of course. In that way we have two cloths: this one and also another piece of cloth, on which I stepped when they put me on the wedding shoe ${ }^{14}$.

I nie vsichko si osiguriavakhme. Platnoto go donese vodeshchiia. Samo che pri nas traditsiiata s platnoto e druga - koito go sabere sled kato minat mladozhentsite negova shche e sledvashchata svatba.

We bought all things. The cloth was given to us by the organiser [of the wedding]. But our tradition regarding the cloth is different: the newlyweds pass on it; then somebody folds the cloth. There is a belief that the person who rolls it up behind the newlyweds will be the next one to get married.

Za prav pat chuvam za tozi obichai, no zvuchi priiatno.

I have never heard of this ritual but it sounds interesting.

Pri nas vsichki tezi neshcha biakha ot restoranta. Ne sme chupili chashite $i$ ne sme si vzimali platnoto - veche si imame 1 - tova, s keto svekarva mi ni posreshchna kato otidokh da zhiveia pri miloto, za kakvo sa ni 2? Inache, nego si go pazim sganato $v$ garderoba. 


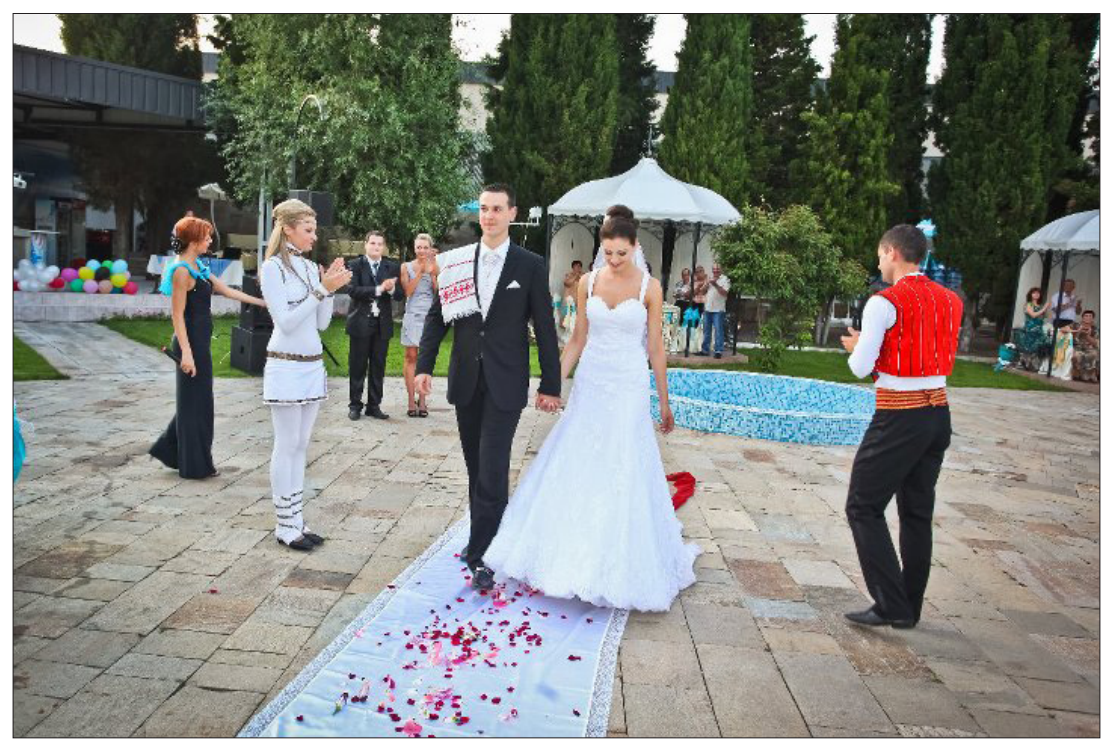

Figure 2. Restaurant garden. The bride and the groom are walking on the white cloth. Photograph by Todor Ivanov 2010.

We got all these things at the restaurant. We did not break the glasses and we did not take the white cloth home. We already had one: the one with which my mother-in-law welcomed us when I entered my husband's home for the first time. Why do we need two cloths? However, we keep this one folded in the wardrobe.

\section{INTERPRETATION: CONTEMPORARY AND TRADITIONAL PERSPECTIVES}

Following the method of exact comparison, the white cloth and the ritual actions that are performed on it could be juxtaposed with its usage in the traditional Bulgarian wedding ritual, at which the bride passes on a white string or a white cloth when entering the bridegroom's house. A new white cloth is usually used for that purpose, and it is spread from the fireplace or the threshold of a traditional house to the place where the newlyweds are welcomed (more often in the yard). The brother-in-law or the mother-in-law has to lead the bride when she passes on the cloth, and it has to be folded behind them. In front of the 
stairs or on the doorstep she stops (SbNU 1891b: 60) and makes a bow (SbNU 1891a: 42). Long towels, white stockings (Ivanova 1984: 118), a rug, or a white cloth with a martenits ${ }^{15}$, which is a traditional Bulgarian item made of coiled red and white string (Ivanova 1984: 118), could be used instead of the cloth (Hadzinikolov 1980: 404). In some villages the bride takes a step on a string of woollen yarn, which one of her sisters-in-law uncoils from the threshold to the fireplace (SbNU 1935: 248).

In traditional culture sometimes the bride steps on the cloth immediately after dismounting the horse. In some regions two women, who were married a year before, uncoil a string from a red woollen ball. Its end is placed on the threshold. The bridegroom has to pass on the string first, starting with his right foot, and is followed by the bride who must do the same (SbNU 1892: 59). The groom's mother coils the string and says: "I am bringing together home and house for the young couple" (ibid.: 57).

On the basis of my fieldwork, as well as more general and comparative materials, I see the white cloth as a ritual object in present days, as an implication of kinship and a way of its symbolic presentation, transmission and assumption. This object is functioning in the sphere of symbolic thinking since it is bought by the groom's mother; at the next moment the couple passes on it and after that it again transforms into an object that belongs in the sphere of ritual practice of the mother-in-law: she has to sew it into a bedsheet for the couple's first child. In fact, this process holds the characteristics of ritual sewing rather than of an everyday action, as the cloth materialises the symbolic relation among three generations, presented by the mother-in-law, the newlyweds and their child. The ritual of the symbolic delivery of the flame may also refer to that idea and may be connected with the symbolic meaning of the cloth as a kinship link.

From this point of view - functioning in the perspective of social relations today - the cloth expresses the ritual relation among generations. In this way the ritual not only reveals symbolically the link between the individual and society and the link between the different groups existing in society, but it also relates human communities in the course of time (Zhivkov 1981: 16). Moreover, the white cloth assumes functions similar to a traditional ritual object because as a ritual object it regulates the relation person-society and realises the adoption of social knowledge (ibid.). One can push the analyses further and demonstrate that the ritual actions performed with the white cloth in the contemporary urban wedding could be seen in the light of continuity of tradition, as an endorsement of the standpoint that there is a lack of a firm boundary between traditional and contemporary culture, or even regarding the present day as a development process of the tradition (Ivanova 2002: 16). 
Thus, the white cloth in a present-day wedding could be interpreted by way of comparison with the symbolism of the cloth in traditional culture. The idea of a gradual incorporation and socialisation of the child exists in traditional culture and one of its realisations is the presence of the father's shirt or mother's chemise among the baby's clothes. In some respect, the mediatory function of the garment personifies the kinship relation between parents and children and the transmission of virtues from a parent to a child. To some extent, the white cloth in a contemporary wedding is an object that transfers socially significant information in a similar way. Here we could draw a comparison with the signification of the white cloth in traditional culture. In Bulgarian traditional culture, the white woven garment, without complementary ornaments and colours, acquires the meaning of 'natural', 'uncultured', and is therefore, to some extent, equal to nakedness. The child that comes into the world naked is wrapped into a baby napkin - a piece of white cloth. It is the first sign of the baby's incorporation in the cultural space, provided that at the moment of birth they are naked and therefore nearer to nature. Transition from a 'covered' with a cloth to a 'dressed' body is regarded as the next step of 'culture' towards mastering the 'nature' (Stanoeva 1994: 74-81). The white colour in Slavic traditional culture is one of the main elements of colour symbolism and white-black colour dualism, finding equivalents in terms such as: white = 'good', 'masculine', 'alive', 'young', 'sacred', 'fertile', etc., and black = 'the worst', 'feminine', 'dead', 'old', 'profane', 'infertile'. The concept of the "kingdom of darkness" as afterlife, opposed to the "white world", is common to all Slavic peoples. The white mourning garments are common in many Slavic societies. In Slavic traditional culture ghosts and mythological characters are represented as dressed in white clothes; yet, women performing ritual actions are also dressed in white (Tolstoi 1995: 151-154). In addition, white is a widely spread colour in traditional Bulgarian culture, which usually designates the ritual status of persons and objects during the initiation rituals of the life circle (many traditional rites are made by people wearing white clothes).

Furthermore, in traditional culture knitting, weaving and spinning are regarded as typical women's activities that separate one part of society from the other: the female part from the male part that is traditionally occupied with ploughing, hunting and war. In many myths and rites, so-called women's activities encode the virginal status of the girl. Myth and rite, as well as fairy tale and epos, are centred on the critical intersections of the life of archaic man, which constitute a transitional period between two social statuses (Marazov 1992: 187-203). For example, in Bulgarian folklore, when women left home, they had to take a distaff with them, and spin or knit, because it was believed 
that in that way they were protected from evil forces, i.e., they protected their status of a girl or a faithful wife (Marazov 1992: 187-203).

Traditional culture has provided us with numerous points of comparison. The cloth as an object, signifying the specific social status of the woman, could be observed in a Bulgarian traditional song that tells us about a bachelor that kidnaps a maiden by tempting her with gifts, loaded up on a sailing boat (Miladinovi 1861). The maiden sets a condition that she will go with him if he spreads out a cloth from the gates of her house to the sailing boat. The bachelor fulfils her wish but kidnaps her when she sets foot on the sailing boat. When the maiden steps on the cloth, she is already taken under the man's control. Once the women's work (waving, knitting and spinning) is completed, nothing else protects the virginal status of the maiden. The cloth, a result of female activity, is converted into a classifier of a successful passage, i.e., an effected change of the social status of the maiden (Marazov 1992: 187-203).

Yet another aspect of the meaning of the white cloth in a contemporary wedding that has to be mentioned is its fertility function. It has to assure fertility of the family, i.e., the cloth acquires magical and protective qualities, like many other traditional items, although it is difficult to determine to what extent the informants really believe in its magical qualities. The $\mathrm{DJ}^{16}$ at the restaurant pronounces wishes for many offspring while the couple is still walking on the cloth.

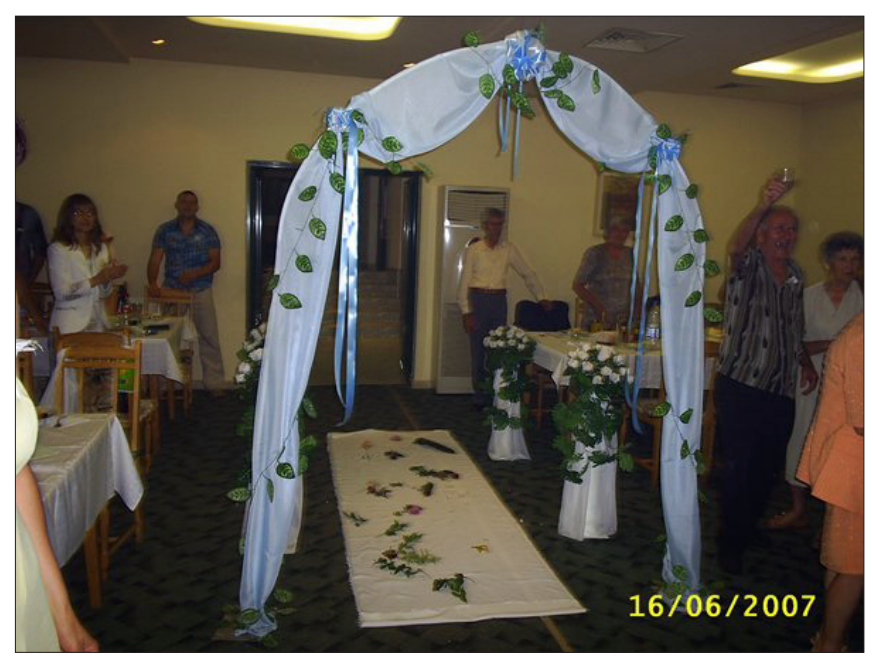

Figure 3. The white cloth placed on the floor in a restaurant in Plovdiv. Photograph by Rozaliya Guigova 2007. 


\section{THE CLOTH AND THE WEDDING PROCESSION AS METAPHORS OF THE WAY}

From another viewpoint, except in social perspective, the cloth as a ritual item functioning in the restaurant can also be regarded as a realisation of a rite of passage. Both the contemporary urban wedding and the traditional one symbolically indicate the bride's transitional status by rites that signify leaving the maternal home, travelling, welcoming and reception by the mother-in-law (Ivanova 1984: 120). The white cloth in the traditional Bulgarian wedding, the thread, the rug, the towel, stockings, or their contemporary version - the white cloth in the restaurant - can be regarded as a symbolic signification of the way, passage and transmission. For a maiden, this way is a passage from one social status to another, from one clan to another, from one home to another. The cloth's mythological one-way direction is emphasised by the rite: according to some informants, in the contemporary urban wedding ceremony the cloth has to be folded by the best man and best woman immediately after the couple's passing and given to the bride. Another contemporary example is the prohibition imposed on the couple to never look back while passing. A comparison can be drawn with the traditional wedding ceremony, in which participants never take the same way back after the church ritual, but choose another way. In the traditional wedding ceremony matchmakers are not allowed to return along the same road that they took when going to the bride's home, because it is believed that otherwise the bride will become a widow and go back to her parents (SbNUNK 1905: 16).

In scientific literature, the wedding is regarded as a rite of passage, expressed in the opposition 'familiar-alien', which is fundamental in the system of mythical thought. In wedding rites this opposition is regarded on a social plane, as the bride's family is differentiated from the groom's family, i.e., the "rites of passage" (Van Gennep 1909) are based on the idea of transmission. The initiation is regarded as a classical example of a rite of passage. Three levels underlying every rite of passage are outlined: separation of the sexually mature young man from his mother and sisters (from the group of the uninitiated women and children), passing through a period of trial and communication with demonical forces, and finally his incorporation in the group of adult men ready for marriage. These components of the rite are also investigated by V. Propp, who takes the fairy tale as an example (Propp 1995). According to the scientific investigations of the traditional Bulgarian wedding ceremony, the function of the initiation is taken over by other rites, for example, the wedding. The main function of the initiation - trial of the adolescent - is realised at different levels in the engagement rites and wedding ceremonies (Ivanova 1984: 142). 
Similarly to the white cloth in the restaurant, the wedding procession today can also be regarded as a metaphor of the path and the passage. No matter whether it consists of horses and carts (in a traditional wedding), or of special luxury cars and limousines, often rented specially for the occasion and decorated with flowers and balloons (in a contemporary situation), it is always an obligatory part of the rite. Its diligent organisation and conduct is a proof of its stability as a folkloric and social notion. In many contemporary Bulgarian urban wedding ceremonies the groom, accompanied by the best man, musicians and a special procession of decorated cars, goes to the bride's home, to pick her up and bring her to the registry office, and after that to church. That could be regarded as a paradoxical conduct nowadays, as the boy and the girl usually live together for many months or years prior to their wedding day - in the girl's flat, in the boy's flat, or, more often, in lodgings. My informants told me that nowadays some brides even go to their parents' home a day before the wedding party so that the groom can come and pick them up from there. Sometimes, when the parents can afford such a big expenditure, the bride goes to her parents' town, even if she lives and works in another town. The big wedding procession travels to her parents' home in order to pick her up ceremonially; after that the car procession goes to the groom's town, and only then the wedding party can start. There are also occasions when the bride goes to her neighbour's apartment and awaits the wedding procession and the groom to come there and take her along, because she rejects the idea of the groom taking her from their common and usually rented flat. Thus, the path and the wedding procession become an important part of the wedding even nowadays and are often designated with many ritual practices and dances.

In spite of the fact that from a present-day point of view it can be interpreted as an anachronism, the groom, as if according to an unconscious logic of belief, makes an effort to bring his wife to his home as officially and ritually as possible. He seems to believe that this is a more reliable way to legalise his marriage than to put a mere signature in the registry office or conclude a religious marriage. Here I could make a comparison with traditional culture, according to which at the groom's home threshold the rites with the white cloth and bread-eating are performed, which symbolise the bride's incorporation into her new home. It is obvious that the procession is an important ritual action, as it is always performed in cars and never on foot, even if the bride lives in the neighbourhood. The procession always moves slowly, symbolising a long travel, and in this way the cars also assume the functions of ritual items. The participants consider the space between the two houses as ritual and symbolical, and they pass it in a ritual way, differentiating it from the mundane urban space. This procession can also be investigated in connection with the traditional ritual of kidnapping the bride. 


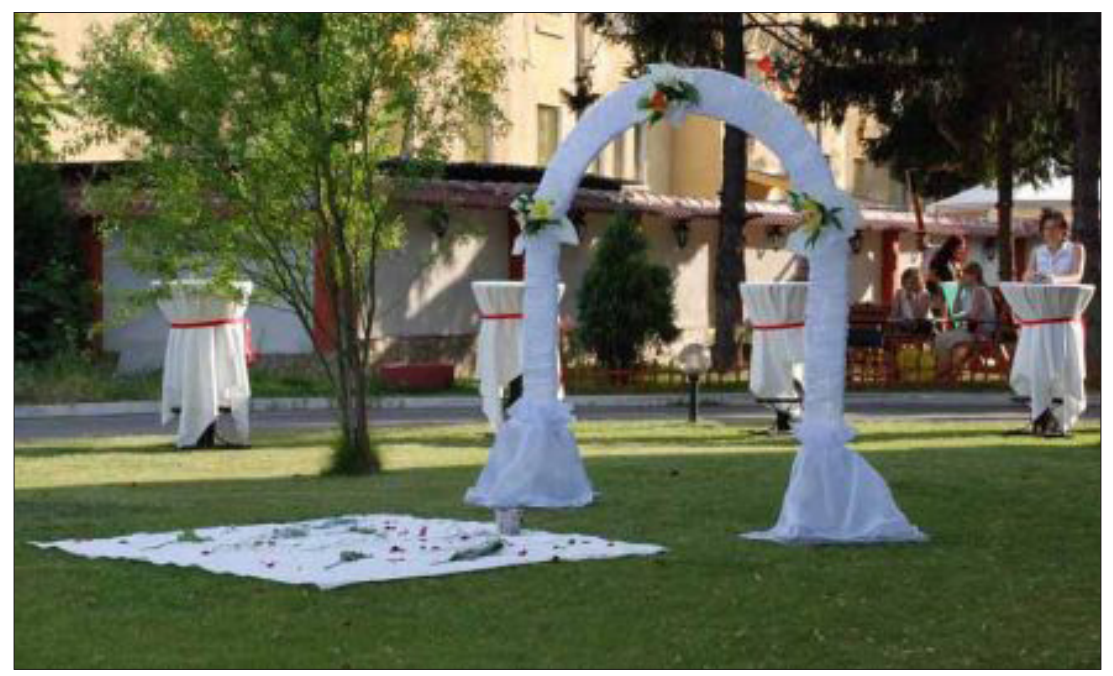

Figure 4. The white cloth laid out in the garden of a restaurant in Sofia. Photograph by Rozaliya Guigova 2008.

\section{POSSIBLE INTERPRETATION OF THE SPATIAL DIMENSIONS OF THE CLOTH}

Today, the cloth's function has one more meaning with regard to its special position and orientation. In this sense, a comparison can be made with the position of the item in the traditional wedding, in which the cloth follows the way from the yard - the place where the couple is welcomed - to the threshold of the house. In traditional culture these spaces symbolically signify border zones which have to be passed ritually by the bride in order to confirm her incorporation into her new home. Sometimes the cloth is spread out up to the fireplace, which in the traditional culture is regarded as the 'centre' of not only the home, but also of the 'cultural space' as a whole, as well as a symbol of the family and kinship. According to Baiburin, the special symbolism of doors and windows in traditional culture is explained by the fact that the meaning assigned to them as border objects is further complicated by their specific implementation: to ensure permeability through boundaries. The borders and the way through them are mythologised, as the door and the window are correlated with the notion of entrance; they both connect home with the outside world. Items (and the cloth in particular) functioning in contemporary urban culture could be considered as speech (parlance), by means of which people consciously or unconsciously 
communicate and fix boundaries between the public and private spheres of their existence. In the intimacy of the notion 'at home', items no more exist as 'goods', as far as we separate them from a great number of similar objects that are products of batch production. The person can transform his or her living space by means of surrounding objects (Chevalier 1995: 95).

Today the ritual with the white cloth is performed in urban environment and takes place in a restaurant. The traditional dwelling house with its thresholds, fireplace, many rooms, cellars, attics and yards, has many spaces that have a mythological meaning and that cannot be discovered in the city and in urban dwellings. In traditional culture, there have been such transitional zones between 'personal' and 'alien', between 'private' and 'public' spaces, between 'outside' and 'inside', as, for example, the yard and the threshold where the ritual with the cloth takes place. Today, the decoration of the entrance with plants and small objects indicates special expansion of the domestic sphere outside home walls. The domestic space is considered as an opposition to the public space, and home is fancied as a closed space, which is safe and secure (Krastanova 2003).

From this point of view, the restaurant could also be considered as a mediating space in urban architecture. The restaurant is converted into simultaneously 'private' and 'public', 'personal' and 'alien' space. The cloth is spread out from the entrance of the restaurant to its interior, where the wedding table is situated. Therefore one of its ends signifies exterior space and the other signifies interior space, or the groom's home, where the wedding table is placed. In this case, it is related to the fact that in many urban weddings today, at the end of the cloth the groom takes the bride in his lap - an action that in traditional culture he performed on the threshold of his home - in order to take her to the wedding table. Today, on the cloth's edge the groom's mother feeds the couple with bread and honey, but in traditional culture this action was performed on the threshold of the groom's home. In many contemporary wedding ceremonies, the space of a restaurant is preferred by the participants, but sometimes the cloth is also laid on the home threshold. It is interesting to mention that at some urban weddings, in the restaurant and near it, the cloth is put on a metal 'hedge', covered with white decorations, which reminds of a house fence. There is a curving arc above the cloth that reminds of a house gate.

Nowadays, the construction of high residential buildings with a great many flats, common staircases and landings between them, implies a lack of such type of mediatory zone between personal and public spaces, as, for example, the yard. Sometimes, the yard is much distanced from the flats as the building has many floors. That is why when citizens try to transfer a custom from the 
Figure 5. Newlyweds on the cloth. Sofia. Photograph by Todor Ivanov 2009.

village to the city very literally, the process can sometimes be difficult and even amusing:

The bride has to sweep the yard, has to demonstrate that she cares for that guy; that she is prepared for him; that she has cleaned up. The bride lived on the sixth floor and she swept the staircase from top to bottom. That was an engagement

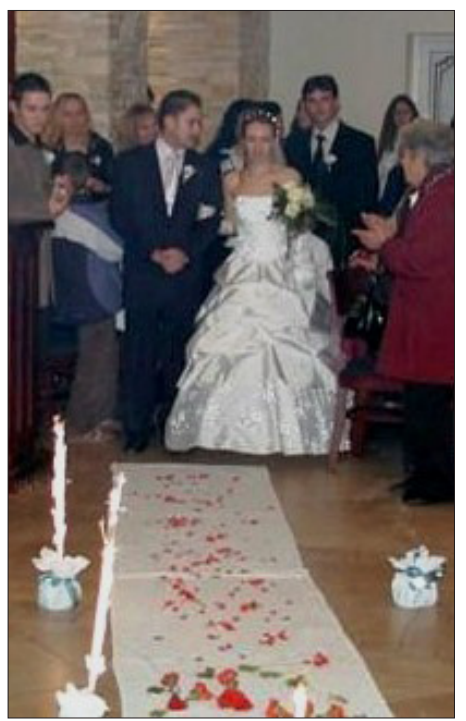
custom. ${ }^{17}$

In this situation the staircase in the block of flats functions as a mediatory spatial zone between private and public spheres. The space structure in a multistorey block of flats is imposed on the inhabitants and they cannot change it but have to comply with the standard and functional dwellings by adapting themselves to nearly similar spatial conditions.

\section{CONCLUSIONS}

What I would like to suggest is that a range of ritual practices in the contemporary urban Bulgarian wedding are no longer associated with the traditional culture. The ritual practices involving the white cloth in the traditional wedding are performed by the groom's mother, as far as it bears the meaning of incorporation of a new member into a family or a clan. That is why the groom's mother in a traditional wedding offers a morsel of bread and sugar, raisins, honey, and apples to the newlyweds before they enter the groom's house. The bride is obliged to eat them and it is believed that by doing so she will secure "a happy life" with her. Today, in some weddings this ritual action is performed by the groom's mother, but often also by a random person from the restaurant staff, a restaurant singer or DJ, who have nothing in common with the bride's or groom's family and whose job is to carry out those ritual actions. Thus, many ritual items in the contemporary wedding ceremony obtain the meaning of continuity of tradition and lose or change their traditional symbolic meaning. The 
meaning of many beliefs today, associated with the objects functioning in the wedding ceremony, is merely to "bring good luck" or "attack bad forces". Some traditions are also maintained "because in my family it has always been done in that way" or because "my mother-in-law always says that", and therefore the meaning of some customs and ritual objects may have culturally changed and their performance is grounded on the authority imposed by the older members of the family, or is related to the private life, the childhood, and family traditions of the informants, and this is why they continue performing them. In this sense it is interesting that the informants often give their own interpretations of the ritual actions and objects that have nothing in common either with the meaning of the traditional ritual practices or with the interpretations made by ethnologists.

On the other hand, the white cloth, as many other objects, definitely acquires a communication function. It means that there is a code, by means of which transfer of information is realised. The objects are elements of that code and therefore they can acquire meaning. Contemporary items not only "speak" about implementation, but also signify the place of their owners in the public sphere. In many cases the impact of the items on the person is a result of the person "reading" the message on some level (Segal 1968: 39). In other words, the object can be seen as a "speech". Artefacts are mediums by which we give form to, and come to an understanding of, ourselves, others, or abstractions such as 'the nation' or 'the modern' (Miller 1994: 397). Through the medium of the objects and the way in which they are perceived it is possible to understand the meaning of society, culture, and their interrelation with time and space (Serkle 2000: 81). In this sense, in the perspective of social relations today, the white cloth as a ritual item preserves, to some extent, its signification function, marking inter-family kinship relations and some notions regarding the symbolic space, maybe because it is correlated with the private life and kinship relations of its owners or the people that have been put in contact with it.

\section{NOTES}

1 I started my fieldwork and investigation for this article when I was a PhD student at the Institute of Folklore in Sofia. I wrote my PhD thesis under the supervision of Prof. Dr. Valentin Angelov. Later on I studied comparable forms of material culture and developed the structure and theoretical framework of the article at the University of Vienna, under the supervision of Prof. Dr. Thomas Fillitz, thanks to OeAD scholarship. 
2 Sofia is the capital and the largest city of Bulgaria, with a population of around 1.2 million people, situated in the western part of the country and approximately at the centre of the Balkan Peninsula. Urbanisation and a considerable immigration to the capital from poorer regions of the country are among the main reasons for the increase of population in Sofia. The population is made up of $96.4 \%$ ethnic Bulgarians. Stara Zagora is a city in Bulgaria, and a nationally important economic centre, which is located in southern Bulgaria. The city has a population of 138,272 inhabitants. The agglomeration of Stara Zagora is the fifth largest in Bulgaria. Svilengrad is a town in south-central Bulgaria, situated at the borders of Turkey and Greece, and is the administrative centre of the eponymous Svilengrad Municipality. The town has a population of 18,132 inhabitants.

3 Varna is the largest city and seaside resort on the Bulgarian Black Sea Coast and the third largest city in Bulgaria after Sofia and Plovdiv, with a population of 334,870 inhabitants as of February 2011. Plovdiv is the second largest city in Bulgaria after the capital Sofia, with a population of 338,153 inhabitants.

4 The informant is a 65-year-old pensioner who has worked all her life as a history teacher at a high school. She narrates about her daughter's wedding in Stara Zagora city in 1996.

5 The sponsors (kumove) in traditional Bulgarian culture are very important figures in many rituals, such as, for example, the wedding. In many Orthodox churches (Serbian, Greek, Bulgarian) usually the best man (kum) or the bridesmaid (kuma) at the wedding acts as a godparent (krastnik) to the first child born into the family. The godfather is responsible for naming the child. The godparent to the child will then act as a sponsor at the child's wedding. Godparents are expected to be in good standing in the Orthodox Church.

6 The informant is a 23-year-old student who narrates about her brother's wedding in the city of Svilengrad in 2001.

7 The informant is a 40-year-old librarian narrating about her wedding in Stara Zagora in 1982.

8 The preparation of the ritual bread (obreden khliab) in traditional Bulgarian culture is a significant part of the rituals of the life-circle. As a bloodless sacrifice, it symbolises fertility and well-being of the family. Richly decorated with chicks, lambs, vine, shepherds, or a ploughman with a plough, modelled in dough, the ritual breads were prepared for baptisms and weddings.

9 This is a traditional metal jug used to carry water and used in many ritual practices in traditional Bulgarian culture. Today it can be bought in every souvenir shop in the country, but some young families have it from their parents.

10 The informant is a 25-year-old university student who narrates about her wedding in 1999.

11 The informant is a 45-year-old mathematics teacher and DJ acting at weddings and other celebrations. I conducted interviews and assisted at a wedding organised by him in Stara Zagora in 2002. 
${ }^{12}$ I found this forum on a web page dedicated to weddings: http://www.svatbata.org (last accessed on January 30,2013). Sometimes the girls put down the name of the city where they live, and the date. For example, the city where the first interlocutor lives is not known but the date can be seen: she wrote the question in 2006 . The second interlocutor lives in Plovdiv and answered in the same year. The third one lives in a town named Pernik. The place where the forth interlocutor lives is not known. The fifth one lives in the town called Gorna Oriahovitsa, and her answer in the internet forum dates from 2007. The sixth one lives in Sofia and answered in the same year. The place of residence of the seventh interlocutor is not known, and she wrote in 2009. All of them are young girls that are planning their weddings.

13 The first interlocutor wrote in 2006 but her place of living is unknown; the second one wrote her answer in the same year. The third lives in Sofia and wrote in 2006. The place of living of the forth one is unknown, and her reply dates from the same year. The fifth one's answer also dates back to the same year. The sixth one lives in Sofia, the seventh - in Varna, and she wrote in 2006, and the eighth one lives in Pernik.

14 The custom involving the wedding shoe is very popular in the contemporary urban Bulgarian wedding, and consists in the following: at the bride's home the groom has to find one of her shoes, which has been hidden, and put it on her foot; the bride complains that the shoe is too big and the groom has to put some money in it in order to make it comfortable. Only after performing this action the wedding procession can be launched.

${ }^{15}$ Martenitsa is a small piece of adornment, made of white and red yarn and worn from March 1 until around the end of March (or the first time an individual sees a stork, a swallow, or a budding tree). The month of March, according to Bulgarian folklore, marks the beginning of springtime. Therefore, the first day of March is a traditional holiday associated with sending off the winter and welcoming the spring.

${ }^{16}$ In the contemporary Bulgarian wedding ceremony the DJ performs one of the main ritual roles as he organises the whole celebration in the restaurant. His role is similar to that of a DJ in a discotheque, but he also has to arrange the rituals taking place at the restaurant. In the course of the wedding he often stops the music and talks, in a humorous key, asking the newlyweds or the guests to perform certain ritual actions.

17 The informant is a 23-year-old girl, a university student, who narrates about her brother's wedding in the city of Svilengrad in 2000.

\section{MANUSCRIPT SOURCES}

Interviews conducted between the years 2000 and 2004, in possession of the author 


\section{REFERENCES}

Arnaudov 1934 = Arnaudov, Mikhail. Ochertsi po balgarskiia folklor . [Essays on Bulgarian Folklore.] Sofia: Akademichno izdatelstvo Prof. Marin Drinov.

Askari, Nasreen \& Arthur, Liz 1999. Uncut Cloth: Saris, Shawls, and Sashes. London: Merrell Holberton.

Baiburin 1983 = Baiburin, Al'bert. Zhilishche $v$ obriadakh i predstavleniiakh vostochnykh slavian. [Dwellings in the Rituals and Beliefs of Eastern Slavs.] Leningrad: Nauka.

Serkle 2000 = Serkle, Deni. Predmetat kato rech: da razgledame predmetite kato sotsialni fakti. [Objects as Speech: Object Viewed as Social Facts.] Balgarski folklore, Vol. 1, pp. 81-89. Available at http://www.ceeol.com/aspx/issuedetails. aspx?issueid=1bb6b036-d1ab-4c23-92a9-9d025540f434\&articleid=f84336c8-de8e4754-9372-0df55b8c19ea\#af84336c8-de8e-4754-9372-0df55b8c19ea, last accessed on November 24, 2014.

Chevalier 1995 = Shevalier, Sophie. Etnografski pogled kam vatreshniia dekor v narodnata gradska sreda. [Ethnographic Look at the Interior Design of the Popular Urban Ambience.] In: Etnologiia na malkiia grad. [Ethnology of the Small Town.] Plovdiv: Khristo G. Danov, pp. 89-123.

Gura 2012 = Gura, Aleksandr. Brak $i$ svad'ba v slavianskoi narodnoi kul'ture: Semantika i simvolika. [Marriage and Wedding in Slavic Folk Culture: Semantics and Symbolism.] Moskva: Izdatel'stvo Indrik.

Hadzinikolov 1980 = Khadzhinikolov, Veselin (ed.) Pirinski krai: Etnografski, folklorni $i$ ezikovi prouchvaniia. [Pirin Region: Ethnographic, Folklore and Linguistic Studies.] Sofiia: BAN.

Ivanova 1984 = Ivanova, Radost. Balgarskata folklorna svatba. [Bulgarian Folkloric Wedding.] Sofiia: BAN.

Ivanova 2000 = Ivanova, Radost. Rituali ot zhizneniia tsikal: traditsiia i savremennost. [Rituals of Life Cycle: Tradition and Modernity.] In: Zhizneniiat tsikal. Dokladi ot balgaro-srabska nauchna konferentsiia. [The Life Cycle. Papers from the Bulgarian-Serbian Scientific Conference.] Sofiia: BAN, pp. 156-171.

Ivanova 2002 = Ivanova, Radost. Kultura na krizata, kriza v kulturata. [Culture of Crisis, Crisis of Culture.] Sofiia: Izdatelstvo Prof. Marin Drinov.

Ivanova \& Zhivkov 2004 = Radost, Ivanova \& Zhivkov, Todor. Balgarskite obredi . [Bulgarian Customs.] Elektronno izdatelstvo LiterNet, 18.03.2004. Available at http://liternet.bg/publish10/t_iv_zhivkov/obredi.htm, last accessed on November 25, 2014 .

Marazov 1992 = Marazov, Ivan. Filomela-takachka i Bendida-predachka. [Filomela, the Weaver and Bendida, the Spinner.] In: Vidimiiat mit: Izkustvo i mitologiia. [The Visible Myth: Art and Mythology.] Sofiia: Khristo Botev, pp. 187-203.

Miladinovi 1861 = Dimitar \& Konstantin Miladinovi. Balgarski narodni pesni. . Bulgarian Folk Songs.] Zagreb: Knigopechatnitsa na A. Iakicha.

Miller, Daniel 1987. Material Culture and Mass Consumption. Oxford: Basil Blackwell Ltd.

Miller, Daniel 1994. Artefacts and the Meaning of Things. In: Tim Ingold (ed.) Companion Encyclopaedia of Anthropology. London: Routledge, pp. 396-419. 
Perani, Judith M. \& Wolff, Norma H. 1999. Cloth, Dress and Art Patronage in Africa. Oxford \& New York: Berg.

Propp 1995 = Prop, Vladimir. Istoricheski koreni na valshebnata prikazka. [Historical Roots of the Fairy Tale.] Sofiia: IK Prozorets.

SbNU 1891a = Sbornik za narodni umotvoreniia i narodopis. [Folklore and Ethnography Collection.] Vol. 4. Sofiia: BAN.

SbNU $1891 \mathrm{~b}=$ Sbornik za narodni umotvoreniia $\mathrm{i}$ narodopis. [Folklore and Ethnography Collection.] Vol. 5. Sofiia: BAN.

SbNU 1892 = Sbornik za narodni umotvoreniia $i$ narodopis. [Folklore and Ethnography Collection.] Vol. 7. Sofiia: BAN.

SbNU 1935 = Sbornik za narodni umotvoreniia i narodopis. [Folklore and Ethnography Collection.] Vol. 40. Sofiia: BAN.

SbNUNK 1905 = Sbornik narodni umotvoreniia, nauka $i$ knizhnina. [Collection of Folklore, Science and Literature.] Vol. 21. Izdanie na Ministerstvoto na Narodnoto Prosveshchenie.

Segal 1968 = Segal, Dimitrii. Mir veshchei i semiotika. [Material World and Semiotics.] Dekorativnoe iskusstvo SSSR, No. 4, pp. 38-41.

Sofia 1989 = Sofiiski krai: Ezikovedski, lingvistichni $i$ etnografski izsledvaniia. [Sofia Region: Linguistic and Ethnographic Research.] Sofiia.

Stanoeva 1994 = Stanoeva, Iva. Tialoto - golo i oblecheno. [The Human Body - Naked and Dressed.] Balgarski folklor, No. 2, pp. 74-82.

Tolstoi 1995 = Tolstoi, Nikita (ed.) Slavianskie drevnosti: Etnolingvisticheskii slovar'. [Slavic Antiquities: Ethnolinguistic Dictionary.] Vol. 1. Moskva: Institut slavianovedeniia RAN.

Tolstoi 2009 = Tolstoi, Nikita (ed.) Slavianskie drevnosti: Etnolingvisticheskii slovar'. [Slavic Antiquities: Ethnolinguistic Dictionary.] Vol. 4. Moskva: Institut slavianovedeniia RAN.

Zhivkov 1981 = Zhivkov, Todor. Obrednost i obredno izkustvo. [Rituals and Ritual Art.] In: Todor Zhivkov (comp.) Obredi i obreden folklor. [Rituals and Ritual Folklore.] Sofiia: BAN, pp. 7-27.

Uzeniova 2010 = Uzeneva, Elena. Bolgarskaia svad'ba: Etnolingvisticheskoe issledovanie. [Bulgarian Wedding: An Ethnolinguistic Study.] Moskva: Indrik.

Vakarelsky 1974 = Vakarelski, Khristo. Etnografiia na Balgariia. [Bulgarian Ethnography.] Sofiia: Nauka i izkustvo.

Van Gennep, Arnold 1909. Les Rites de Passage. Paris: Emile Nourry.

Weiner, Annette B. \& Schneider, Jane (eds.) 1989. Cloth and Human Experience. Washington: Smithsonian Institution Press. 